fournal of Medical Genetics (1975). 12, 204-212.

\section{A patient with congenital anomalies and a deletion of the long arm of chromosome 4 $[46, \mathrm{XY}, \operatorname{del}(4)(\mathrm{q} 31)]$}

Summary. This paper describes the clinical symptoms and cytogenetic findings in a patient previously described in a doctoral thesis (van Kempen, 1969). The patient is a boy with multiple congenital anomalies and a deletion of the long arm of chromosome 4. A recent Giemsa banding study showed absence of the terminal G-band, as was found in the patient described by Golbus et al (1973). The symptoms and other data on the three patients known to have a deletion of the long arm of chromosome 4 are presented to facilitate comparison of these cases. However, the number of cases so far on record is too small to warrant conclusions on the basis of this comparison.

A recent report on a female patient with deletion of the terminal G-band of the long arm of chromosome 4 (Golbus et al, 1973) prompted me to submit the following report on a male patient with a similar chromosomal anomaly, previously described in a doctoral thesis (van Kempen, 1969). In this study the deleted chromosome was identified by autoradiography. Our laboratory has recently made a Giemsa banding study of the karyotype, which confirmed the earlier finding that chromosome 4 was involved and in addition revealed the absence of the terminal G-band.

The first patient in whom a deletion from the long arm of chromosome 4 was demonstrated, was described by Ockey et al (1967), who identified the

Received 28 May 1974. chromosome by autoradiography and did not specify the location of the deleted fragment on the long arm.

On the basis of the following case report, I intend to discuss the phenotype and other data of the three patients so far described.

\section{Case report}

The propositus is the second child of a 29 -year-old father and a 26-year-old mother. Pregnancy was uneventful and ended at term. Birth weight was $2430 \mathrm{~g}$. The infant was evidently asphytic, and therefore treated with oxygen. He proved to be a 'strange-looking' baby with cheilo-palatoschisis.

The boy (Figs. 1a and 1b) was admitted to our Institute for observation at age 6 years 5 months.

Positive physical findings included retarded growth; marked venous pattern on the face, neck, and cranial part of the thorax; microcephaly; distinct facial asymmetry and some effacement of facial features; fairly thin

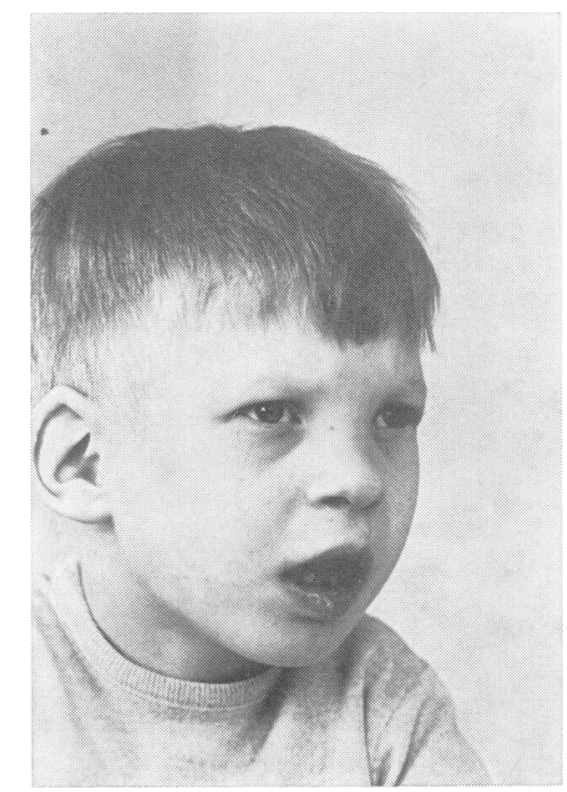

FIG. 1a 


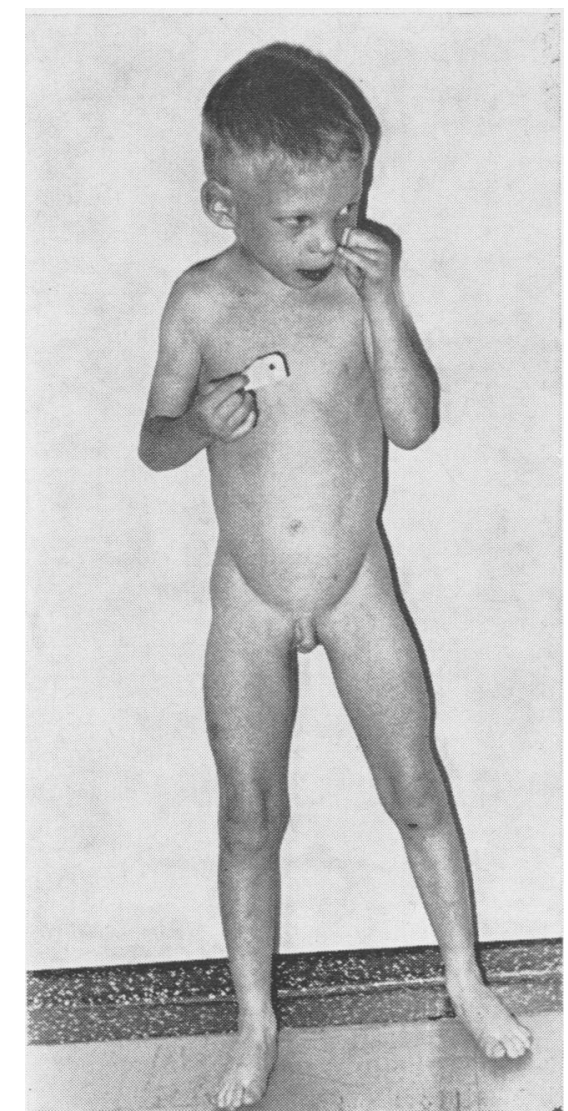

FIG. 1b

and dry scalp hair; hypertelorism; bilateral epicanthus; ears with pointed pinnae (satyr ears); flat, broad nasal base ; cheiloschisis cicatrix ; mild micrognathia ; open bite; small, malaligned teeth, with absence of one upper incisor while the middle one of the remaining three seems to have two segments; funnel chest; widely spaced nipples; slight enlargement of the heart to the left at percussion; early systolic souffle over all ostia, particularly on the right over the base of the heart; mild hypospadias; undescended testicles as yet and very small scrotum; winged scapulae; mild thoracic scoliosis; sacral dimple; mild limitation of extension in both elbows, particularly on the right; poorly developed palmar relief; broad hands; bilateral clinodactyly; bilateral mild partial syndactylism between the third and fourth toes; pedes plani valgi; obvious hypotonia; plantar reflexes according to Babinski on both sides.

The resting EEG with open eyes showed dominant $\beta$ activity, more marked on the right than on the left; considerable build-up during deep breathing; asymmetry, with slightly lower frequencies and higher voltages on the right. A subsequent EEG (at age 10 years 10 months) showed changes, characteristic of generalized epilepsy, throughout the registration. Pneumo-ventriculography was normal; ophthalmological examination revealed only bilateral hypermetropia. Audiometric findings indicated the likelihood that the patient is not deaf, although the possibility of some hearing deficiency remains. Skeletal radiology was suggestive of the presence of spina bifida and also revealed a bilateral cervical rib and retarded bone age (of about 4 years). Chest radiology disclosed a very convex heart with a wide unrolled aorta. Cardiological examination led to the conclusion that the findings were most suggestive of a functional murmur. A subsequent ECG (at age 14 years 4 months) was conclusive of a normal left heart with incomplete right bundle-branch block and ventricular extrasystoles of a left bundle-branch block type.

IVP was normal. Biochemical analysis of blood and urine revealed no abnormality other than a subnormal haemoglobin concentration, a subnormal serum iron level, and a subnormal polymorphonuclear lobe count.

Psychological examination revealed a boy functioning on the level of idiocy, with numerous behavioural disorders; possibilities of learning and upbringing were concluded to be poor.

\section{Chromosome studies}

A chromosome study (Fig. 2) was made in cultured peripheral lymphocytes and skin fibroblasts, and showed the modal number of chromosomes to be 46; one of the B-group chromosomes was characterized by a deletion of the long arm. Autoradiographic examination disclosed that the deleted chromosome belonged to pair No.4. Very recently, a G-banding study was made by a slight modification of Seabright's method (1972). It confirmed the earlier identification of the deleted chromosome and also revealed that the deletion involved the terminal G-band. The karyotype can therefore be represented as: $46, X Y, \operatorname{del}(4)(q 31)$ or $46, X Y, d e l(4)$ (pter $\rightarrow$ q31) (Paris Conference, 1971).

No abnormalities were found in the parents' karyotypes.

\section{Dermatoglyphs}

Dermatoglyphs revealed on the right: axial triradius in $t^{\prime}$ position; four-finger line; very poor development of the interphalangeal flexor creases on IV and the distal flexor crease on V; vague indication of a flexor crease between the distal and the proximal flexor crease on III. Left: axial triradius in $t^{\prime}$ position; absence of the interphalangeal flexor creases on $\mathrm{V}$.

\section{Discussion}

Although a deletion from the long arm of chromosome 4 was demonstrated with certainty in the 


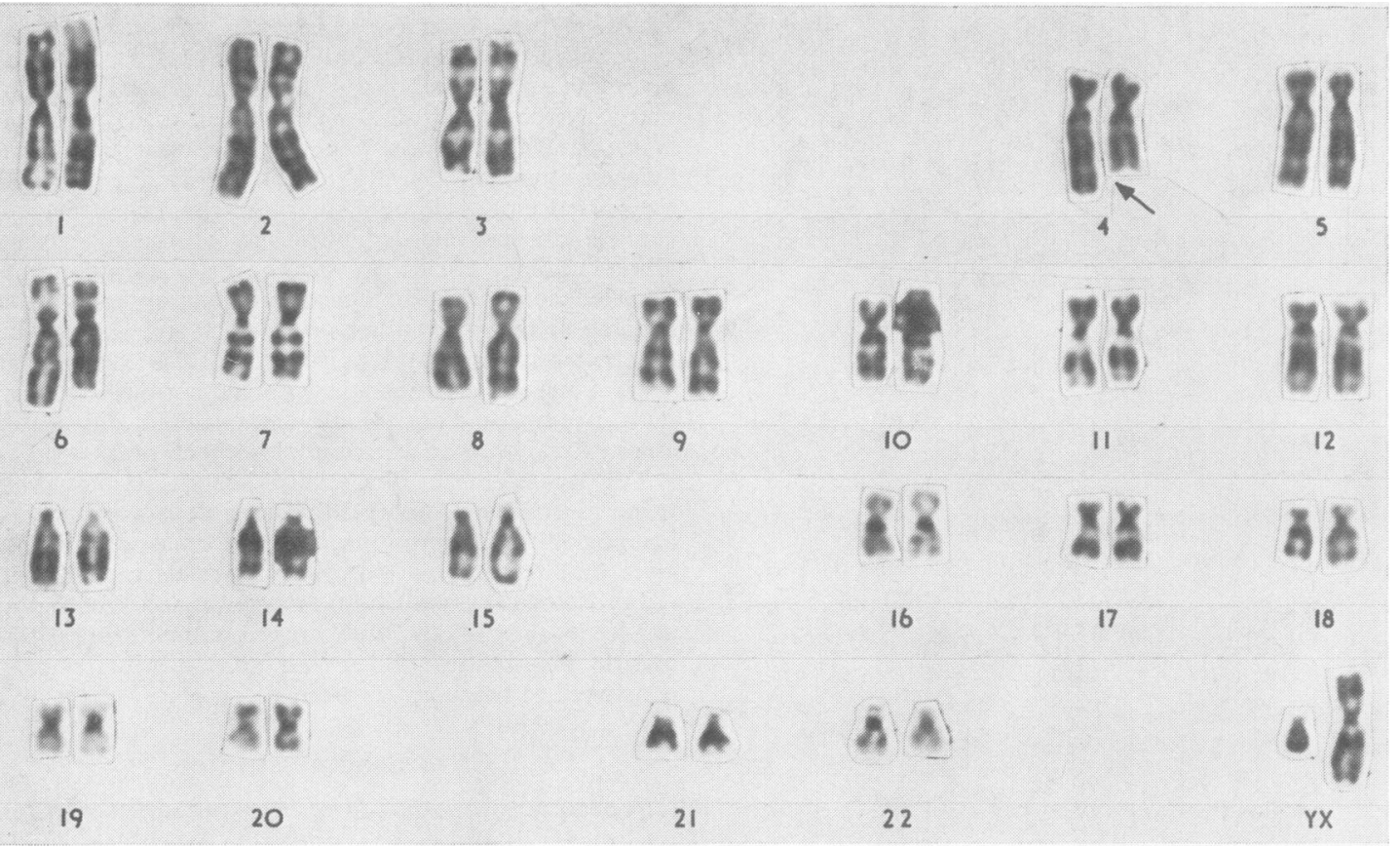

FIG. 2. Karyotype from peripheral blood with Giemsa banding.

TABLE I

SYMPTOMS AND OTHER FINDINGS CONCERNING PATIENTS WITH DELETION OF THE LONG ARM OF CHROMOSOME 4

\begin{tabular}{|c|c|c|c|c|c|c|c|}
\hline & Case 1 & Case 2 & Case 3 & & Case 1 & Case 2 & Case 3 \\
\hline Reference & $\begin{array}{c}\text { Ockey et al } \\
(1967)\end{array}$ & $\underset{(1973)}{\text { Golbus et al }}$ & $\begin{array}{c}\text { Present } \\
\text { Case }\end{array}$ & Reference & $\begin{array}{c}\text { Ockey et al } \\
\text { (1967) }\end{array}$ & $\underset{(1973)}{\text { Golbus et al }}$ & $\begin{array}{l}\text { Present } \\
\text { Case }\end{array}$ \\
\hline $\begin{array}{l}\text { Duration of pregnancy (weeks) } \\
\text { Birth weight (g) } \\
\text { Sex } \\
\text { Birth order } \\
\text { Paternal age at child's birth } \\
\text { Maternal age at child's birth } \\
\text { Age at examination }\end{array}$ & $\begin{array}{r}40 \\
3600 \\
M \\
1 \\
19 \\
19 \\
3 \text { mth } \\
\end{array}$ & $\begin{array}{r}40 \\
3360 \\
F \\
1 \\
21 \\
22 \\
1-6 \text { mth }\end{array}$ & $\begin{array}{r}36 \\
2430 \\
M \\
2 \\
30 \\
26 \\
6 \frac{1}{2}-14 \frac{1}{3} \mathrm{yr}\end{array}$ & \multirow{2}{*}{$\begin{array}{l}\text { Pectus excavatum } \\
\text { Wide spaced nipples } \\
\text { Cardiac defects } \\
\text { Recurrent respiratory infections } \\
\text { Enlarged liver } \\
\text { Umbilical hernia } \\
\text { Renal anomalies } \\
\text { Sacral dimple } \\
\text { Hypospadias } \\
\text { Limitation of extension at } \\
\text { elbows } \\
\text { Radial anomalies } \\
\text { Webbing of fingers } \\
\text { Clinodactyly of fifth fingers } \\
\text { Short distal phalanx of fifth } \\
\text { fingers } \\
\text { Poorly developed extensor } \\
\text { creases in fingers } \\
\text { Webbing of toes } \\
\text { Displacement of toes } \\
\text { Skeletal anomalies } \\
\text { Retarded bone age } \\
\text { Hypotonus } \\
\text { Cafe au lait spots } \\
\text { EEG anomalies } \\
\text { Seizures } \\
\text { Malrotation of colon }\end{array}$} & $\begin{array}{l}+ \\
+\end{array}$ & $\begin{array}{l}+ \\
+ \\
+ \\
+\end{array}$ & $\begin{array}{l}+ \\
+ \\
+* \\
+ \\
+ \\
+\end{array}$ \\
\hline $\begin{array}{l}\text { Mental retardation } \\
\text { Growth retardation } \\
\text { Microcephaly } \\
\text { Asymmetrical skull } \\
\text { Prominent occiput } \\
\text { Hypertelorism } \\
\text { Mongoloid slanting of eyes } \\
\text { Epicanthal folds } \\
\text { Low set ears } \\
\text { Superiorly pointed ears } \\
\text { Flat nose bridge } \\
\text { Shortened nasal septum } \\
\text { Dental defects } \\
\text { High arched palate } \\
\text { Palatoschisis } \\
\text { Cheiloschisis } \\
\text { Micrognathia } \\
\text { Oropharyngeal hypotonus }\end{array}$ & $\begin{array}{l}+ \\
+ \\
+ \\
+\end{array}$ & $\begin{array}{l}+ \\
+ \\
+\end{array}$ & $\begin{array}{l}+ \\
+ \\
+ \\
+ \\
+ \\
+ \\
+ \\
+ \\
+ \\
+ \\
+ \\
+ \\
+ \\
+ \\
+ \\
+\end{array}$ & & $\begin{array}{l}+ \\
+\end{array}$ & $\begin{array}{l}+ \\
+ \\
+ \\
+ \\
+\end{array}$ & $\begin{array}{l}+ \\
\pm \\
\pm \\
+ \\
+ \\
\pm \\
\pm \\
+ \\
+ \\
+\end{array}$ \\
\hline
\end{tabular}

* These symptoms have become clear during the last years. 
patient described by Ockey et al (1967), it is uncertain whether the deletion involved the same fragment as in the patient of Golbus et al (1973) and our patient, namely the terminal G-band.

The anomalies found in these three patients have been listed in Table I. The cases from the literature in which a ring chromosome 4 was described, have not been included for comparison because this type of anomaly is very likely more complex than that in linear deletion.

The principal value of Table $I$ is to be sought in its use as a basis for comparison if further patients with this chromosomal anomaly are found. The number of cases diagnosed so far is too small to warrant any definite conclusion. In my view, mention may be made of the following striking similarities between cases 2 and 3: the ears with pointed pinnae (satyr ears); palatoschisis; micrognathia; heart defect; sacral dimple; poor development of flexor creases on the fingers.

Perhaps the most specific of these phenomena are the typical dysmorphia of the ears (satyr ears) and the poor development of flexor creases on the fingers; the other phenomena have been described in several other disparate chromosomal anomalies.

In my opinion the small number of patients with 46,XY,del(4)(q31) precludes any definite conclusions of the likelihood of the involvement or noninvolvement of the same fragment in case 1 as in cases 2 and 3.

I accept the statement of Golbus et al (1973) that a syndrome corresponding with this karyotype -deletion (4)(q31) - can be more or less exactly defined only after several patients with this anomaly have become available.

I am indebted to the staff of the cytogenetic laboratory of our Institute, and to Mrs M. Peters-Derksen for her administrative contribution to the preparation of this paper.

\section{VAN KEMPEN Huize 'Maria Roepaan', Institute for Mental Defectives, Ottersum, \\ The Netherlands}

\section{REFERENCES}

Golbus, M. S., Conte, F. A., and Daentl, D. L. (1973). Deletion from the long arm of chromosome $4(46, x \times, 4 q-)$ associated with congenital anomalies. Fournal of Medical Genetics, 10, 83-85.

Kempen, C. van (1969). Vijf Vormen van Autosomale Deletie, Een Klinische en Cytogenetische Studie. $\mathrm{PhD}$ thesis, University of Nijmegen. Janssen, Nijmegen.

Ockey, C. H., Feldman, G. V., Macaulay, M. E., and Delaney, M. J. (1967). A large deletion of the long arm of chromosome no. 4 in a child with limb abnormalities. Archives of Disease in Childhood, 42, 428-434.
Paris Conference (1971). Standardization in human cytogenetics. Birth Defects: Original Article Series, 8, pt. 7, 1972. The National Foundation-March of Dimes, New York.

Seabright, M. (1972). The use of proteolytic enzymes for the mapping of structural rearrangements in the chromosomes of man. Chromosoma, 36, 204-210.

\section{A mentally retarded child with a translocation involving chromosomes 12 and 19}

\author{
Summary. This report concerns a \\ de novo reciprocal translocation between \\ the long arms of the chromosomes 12 and \\ 19 in a mentally retarded child with bi- \\ lateral radioulnar synostosis, agenesis of \\ the corpus callosum, and several minor \\ congenital malformations.
}

Many instances of autosomal translocations in man have been reported. Since the introduction of the banding techniques it is possible to identify the chromosomes involved in the rearrangements. This report concerns a female child with severe psychomotor retardation, bilateral radioulnar synostosis, and agenesis of the corpus callosum. On cytogenetic study, she appeared to have a reciprocal translocation between the long arms of chromosomes 12 and 19.

\section{Case report}

The patient, a girl, is the third child in a sibship of six. Her parents and sibs are phenotypically normal. Her unrelated father and mother were 25 and 23 years old, respectively at the time of her birth. Hereditary abnormalities are unknown among the relatives. Pregnancy was uncomplicated and delivery spontaneous and at term with a birth weight of $3000 \mathrm{~g}$. The neonatal period was uneventful. Psychomotor development was slow during infancy. She did not walk before the age of 2 years.

At examination at $6 \frac{1}{2}$ years, length was $110 \mathrm{~cm}$ and head circumference $52 \mathrm{~cm}$. She showed slight hypertelorism and synophrys. Her ears were low-set and slightly dysmorphic (Fig. 1). Two extra nipples were present on the thorax. Her fingers showed arachnodactyly and there was syndactyly between the second and third toes. A bilateral restriction of pronation-supination movement was noticed. The flexion creases of the hands and feet were normal.

Neurological examination revealed only a subnormal motor development.

Received 28 July 1974. 